\title{
Testing the Information-Based Trading Hypothesis in the Option Market: Evidence from Share Repurchases
}

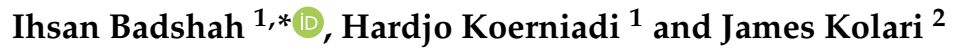 \\ 1 Department of Finance, Auckland University of Technology, Private Bag 92006, Auckland 1142, \\ New Zealand; hardjo.koerniadi@aut.ac.nz \\ 2 Department of Finance, Texas A\&M University, College Station, TX 77843-4218, USA; jkolari@mays.tamu.edu \\ * Correspondence: ihsan.badshah@aut.ac.nz; Tel.: +64-9-921-9999 (ext. 5394)
}

Received: 5 October 2019; Accepted: 28 November 2019; Published: 29 November 2019

\begin{abstract}
The informed options trading hypothesis posits that option prices lead stock prices. In this paper, we extended the research on this hypothesis to open-market share repurchases. Empirical tests showed that the implied volatility spread was not significantly related to buy-and-hold abnormal stock returns. However, further evidence reveal a significant relationship between implied volatility spread and subsequent stock return volatility around open-market share repurchase events. We concluded that option traders have private information on the volatility of stock returns and superior information processing ability that accounts for prescient pricing behavior in options relative to stocks.
\end{abstract}

Keywords: event study; informed trading; options; share repurchase; volatility spread; US equity market

\section{Introduction}

Prior research suggests that informed traders prefer to trade options over stocks due to relatively lower trading costs, higher leverage, limited downside risks, volatility trading, and short sale access (see, e.g., Black 1975; Easley et al. 1998). As such, it is commonly believed that options prices lead stock prices-hereafter called the informed options trading hypothesis. In this regard, a number of studies have found that transactions in options markets contain information content about future stock prices (e.g., Chan et al. 2002; Pan and Poteshman 2006; Roll et al. 2010). A related branch of the literature, however, documents that option investors also trade on the volatility of underlying stock returns (Patell and Wolfson 1981; Chen et al. 2014; Gharghori et al. 2017). A recent study by Hao (2016) found that implied volatility spread, which is an option implied volatility-based measure for informed option trading, can predict the direction of stock returns prior to share repurchase announcements. However, the sample used by Нао (2016) included both open-market repurchase announcements and tender offers as well as negotiated repurchase announcements. Unfortunately, firms undertaking tender offers are subject to relatively stringent disclosure and procedural regulations, and negotiated share repurchases are often initiated by the sellers rather than the corporation (Peyer and Vermaelen 2005). Because these two announcement types are prone to leakage prior to the event, the results may be attributed to these announcements ${ }^{1}$.

1 It is worth noting that Vafeas (1997) found that abnormal stock returns around tender offers are much higher than those of open-market repurchase announcements. Of course, price discovery most likely occurs in the options market when informed options traders expect large changes in stock prices (Holowczak et al. 2006). Hence, the significant relationship between pre-announcement volatility spreads and repurchase announcement returns in Hao (2016) could be attributed to tender offers rather than open-market repurchase announcements. 
We contribute to the literature by examining informed option trading around open-market share repurchase announcements, which are considered to be unscheduled or unanticipated events. Given that firms announcing open-market repurchase programs experience changes in their stock return volatility prior to and after the announcement date (Hsu and Huang 2016; Kim 2007), we tested whether option investors have private information prior to an unanticipated event as well as trade on the direction or volatility of the firms' stock prices. Moreover, we examined option trading in the period immediately after announcements. According to (Kim and Verrecchia 1991, 1994) information-based trading theory, informed investors have better skills in processing information related to an announcement than uninformed investors. Testing for volatility-informed trading in the option market before and after share repurchase announcements is important due to the fact that these events are, on average, positive return events but lower in return magnitude relative to other corporate events. Therefore, it is more suitable for informed option investors to use the option/underlying strategy, particularly by including a long call option in their option trading strategy. In this way, informed investors can benefit via either direction or volatility. Consequently, volatility spread, defined as the difference between call and put volatilities (reflecting deviation from the put-call parity no-arbitrage relation), represents a potential proxy for volatility-informed trading in the option market during share repurchase events.

Our results suggested that options trading before and after open-market share repurchases is based primarily on stock price volatility rather than stock returns. We found insignificant relationships between implied volatility spreads (in three-day pre-event and five-day post-event windows) and buy-and-hold announcement abnormal returns. These insignificant relationships are not surprising in view of the relatively small magnitude of short-term (long-term) announcement returns, i.e., on average only $1.20 \%(0.15 \%)$, respectively. This finding is consistent with Badshah et al. (2019), who documented the absence of directional informed trading in option markets prior to open market share repurchase announcements after the enactment of the SOX in 2002. However, we extended their analyses by examining whether option investors trade on volatilities around this unanticipated event. Consistent with Chen et al. (2014), our tests showed that implied volatility spreads of call and put options before and after the announcement date are significantly related to stock return volatility. Also, our results showed that volatility spreads are significantly related to stock return volatility for selected motivations to launch open-market repurchase programs, which suggests that informed trading occurs in these particular open-market repurchase programs. Our results are robust to using daily changes in implied volatility of call and put options before and after the event as an alternative implied volatility measure (Gharghori et al. 2017). We concluded that options trading around unscheduled open-market stock repurchases is predictive of stock return volatility.

\section{Hypotheses and Research Design}

Prior work by Cremers and Weinbaum (2010) showed that volatility spread, based on the deviation from put-call parity, reflects informed trading in options markets about expected positive changes in underlying asset prices ${ }^{2}$. Volatility spread is calculated as the difference in implied volatility of call and put options matched by the same strike price and maturity date. When a firm's stock price is expected to increase, demand for its call (put) options will increase (decrease) suggesting high call

2 Another implied volatility based measure is volatility skew. However, this measure is related to negative changes in the underlying assets' returns (Xing et al. 2010; Jin et al. 2012; Chan et al. 2015). Because open-market share repurchase announcements are positive corporate events, we utilized volatility spread as our measure of informed trading in options markets (Hao 2016). 
implied volatilities relative to put implied volatility. The volatility spread (VS) of stock $i$ on day $t$ is measured as:

$$
V S_{i, t}=I V_{i, t}^{\text {calls }}-I V_{i, t}^{\text {puts }}=\sum_{j=1}^{N_{i, t}} w_{j, t}^{i}\left(I V_{j, t}^{i, \text { call }}-I V_{j, t}^{i, p u t}\right),
$$

where $I V_{\mathrm{i}, \mathrm{t}}$ is calculated using a binomial tree model adjusted for expected dividends and early exercise, $j$ represents pairs of call and put options matched on the same strike price and maturity date, $w_{i, j}$ are weights using the average open interest in call and put options, and $N_{\mathrm{i}, \mathrm{t}}$ is the number of valid pairs of options on stock $i$ on day $t$.

Following Jin et al. (2012), we utilized a base-window event period from -50 to -11 days prior to the announcement date, pre-event window from -10 to -2 days, and post-event window from +1 to +5 days. Option volatility spreads were computed for each sample stock in these three event windows, which were denoted BASE_SPREAD, PRE_SPREAD, and POST_SPREAD, respectively. The event window was from +1 to -1 days.

Abnormal buy-and-hold returns (BHARs)for the $i$ th stock are computed as follows:

$$
\mathrm{BHAR}_{i t}=\Pi\left(1+r_{i, t}\right)-\Pi\left(1+r_{m, t}\right),
$$

where the CRSP (The Center for Research in Security Prices) value-weighted market return is obtained from Kenneth French's website. Short-term abnormal stock returns (XRET) were estimated from -1 to +1 days around the event. Long-run abnormal returns (POSTRET) were measured from +6 to +90 days after stock repurchase announcement dates.

Since we conjectured that option investors have private information on the direction of stock prices prior to open-market share repurchase announcements, our first hypothesis was:

Hypothesis 1. Implied volatility spread measured in the pre (post) event window is positively related to abnormal stock returns in the event (post-event) period.

Similar to Jin et al. (2012), to examine whether options traders have private information on the direction of stock prices prior to the announcement date as well as superior ability in processing publicly-disclosed information after an event, we employed the following respective regressions:

$$
\begin{aligned}
& \operatorname{XRET}(-1,+1)_{i}=\text { Intercept }+\beta B A S E \_S P R E A D_{i}+\delta P R E_{-} S P R E A D_{i} \\
& +\sum_{j=1}^{N} \gamma_{j} \text { Control Variables } i_{i, j}+\text { Year Effect }+ \text { Industry Effect }+\varepsilon_{i} \\
& \operatorname{POSTRET}(+6,+90)_{i}=\text { Intercept }+\beta B A S E \_S P R E A D_{i}+\delta P R E \_S P R E A D_{i}+\varphi X R E T_{i} \\
& +\phi P O S T \_S P R E A D_{i}+\sum_{j=1}^{N} \gamma_{j} \text { Control Variables } i_{i j}+\text { Year Effect }+ \text { Industry Effect }+\varepsilon_{i} .
\end{aligned}
$$

If volatility spread contains information relevant to expected short-run (long-run) changes in stock prices from the announcements, the coefficient of PRE_SPREAD (POST_SPREAD) should be positively related to XRET (POSTRET). Equations (3) and (4) helped to discern what type of information drives option traders-namely, private information or information processing ability, respectively. Control variables are a dummy variable if a sample firm launched more than one repurchase program during the sample period, the natural logarithm of the market capitalization of sample firms, the book to market ratio of sample firms and the natural logarithm of the dollar authorization value.

An open-market repurchase announcement is an unscheduled event. Because it is unanticipated, option investors may have only partial information on an impending event and therefore may not be able to accurately predict the direction of firms' future stock prices. However, these investors may still trade by betting on stock price volatilities as announcing firms' stock prices around stock 
repurchase announcements exhibit high volatility (Hsu and Huang 2016; Kim 2007). To test whether option investors trade on stock volatility around this event, our second hypothesis was:

Hypothesis 2. Implied volatility spread measured in the pre (post) event window is positively associated with stock return volatility in the event (post-event) period.

Following Gharghori et al. (2017) and Chen et al. (2014), we examined whether option volatility spreads are related to short-run (long-run) stock return volatility based on the following respective regressions:

$$
\begin{aligned}
& \text { STDEVSHORT }_{i}=\text { Intercept }^{+} \beta \text { PRE_SPREAD } \\
& i \\
& \text { STDEVLONG }_{i}=\varepsilon_{i},
\end{aligned}
$$

where STDEVSHORT (STDEVLONG) is the standard deviation of the daily market-adjusted returns in the short-term window period from -1 to +1 days ( +6 to +90 days after the announcement date). Chen et al. (2014) argued that, given informed investors trade on option volatility, option prices may contain predictive information about future realized volatility. When informed trading in options occurs more frequently, this predictability is more pronounced due to higher option liquidity than that of the underlying assets. Here we extended their analyses of Taiwanese markets to U.S. markets.

\section{Sample}

Our equity options data was obtained from the IVolatility database for the sample period 1 January 2000 to 31 December 2011. The database provides daily bid and ask quotes, open interest, volume, implied volatility, and Greeks, such as delta, gamma, vega, and theta, for call and put options listed on all option exchanges for underlying U.S. equities. Options on the individual stocks are American type. Their implied volatilities are calculated using a binomial tree model by accounting for early exercise of stock options and expected dividends to be paid over the entire option life. Our second data source was the Thomson Reuters Securities Data Company (SDC) from which we collected data on non-financial and non-utility firms that announced open-market share repurchase programs during our sample period from 2000 to 2011. Firms that conducted open-market repurchases during our sample period with optionable stocks were then merged with the underlying equity data in DataStream International. Thus, stocks had to meet the following criteria to be included in the sample: information matched across all three data sources, data available for the control variables (viz., market capitalization, book-to-market equity, and dollar authorization value), and non-zero pre-spreads. Additionally, we excluded firms with more than one repurchase per year. Our final sample contained 419 firms' share repurchase events.

As in Cremers and Weinbaum (2010) and Jin et al. (2012), we used the following criteria for options to be included in the sample. We considered options (calls and puts) with maturity from 10 days to 60 days. To address the thin trading issue, we removed options with zero open interest and zero volume. Based on implied volatility data, we calculated the implied volatility spread, wherein call and put options were matched based on strike price and maturity.

Table 1 shows the means of the buy-and-hold returns (BHARs) and volatility spreads. The short-run BHAR in days -1 to +1 averaged $1.20 \%$, which is statistically different from zero. The long-run BHAR in days +6 to +90 averaged $0.15 \%$, but is not statistically significant. The small post-event magnitude of announcement returns was consistent with prior open-market share repurchase studies. The majority of the share repurchasing firms did not clearly declare their motivation to launch an open market share repurchase programs in their announcements. About $73 \%$ of the announcements (304 observations) stated general corporate purpose as the motivation for open market repurchases. The second most commonly stated motivation was related to enhancing shareholder value (75 observations) and the rest were related to offsetting dilution effects, undervaluation, stock option plans, and acquisition purposes. When the sample was split into different subsamples based on stock repurchase motivation, short-term 
BHARs were higher at $12.29 \%$ on average for stock option plan actions, which exceeded other motives by a wide margin. The insignificant announcement return related to stock option plan was due to the low number of observations and high standard deviation of the returns. Long-run BHARs were highest at $3.59 \%$ for the acquisition motive. Interestingly, for the stock option plan, long-run BHARs reversed to a large negative abnormal return of $-15.40 \%$. Further results, as seen in Table 1, suggested that higher short- and long-run BHARs were associated with non-repeat (rather than repeat) repurchase announcements ${ }^{3}$, larger authorization value, smaller firms, value firms, and higher pre-event volatility spreads (PRE_SPREAD) ${ }^{4}$.

Table 1. Mean of announcement returns, base-window spread, pre-event spread, and post-event spread.

\begin{tabular}{|c|c|c|c|c|c|c|}
\hline & XRET & POSTRET & BASE_SPREA & $D P R E \_S P R E A D$ & POST_SPREAD & $N$ \\
\hline Total & $1.20 \% * * *$ & $0.15 \%$ & $0.40 \% * * *$ & $0.56 \% * * *$ & $0.52 \% * * *$ & 419 \\
\hline \multicolumn{7}{|l|}{ Repurchase Motivation } \\
\hline Acquisition purposes & $-2.79 \%$ & $3.59 \%$ & $0.05 \%$ & $0.27 \%$ ** & $1.10 \%$ & 2 \\
\hline Employee benefit plans & $0.91 \%$ & $1.52 \%$ & $0.28 \%$ & $0.91 \%$ & $0.56 \%$ & 6 \\
\hline $\begin{array}{l}\text { Enhance shareholder } \\
\text { value }\end{array}$ & $2.09 \% * * *$ & $-2.03 \%$ & $0.38 \% * * *$ & $0.44 \%$ ** & $0.37 \%$ * & 75 \\
\hline $\begin{array}{l}\text { General corporate } \\
\text { purpose }\end{array}$ & $1.05 \% * * *$ & $0.86 \%$ & $0.43 \% * * *$ & $0.48 \% * * *$ & $0.55 \% * * *$ & 304 \\
\hline Offset dilution effect & $0.70 \%$ & $-1.12 \%$ & $0.42 \%$ * & $1.89 \%$ & $-0.10 \%$ & 19 \\
\hline Stock options plan & $12.29 \%$ & $-15.40 \% * * *$ & $-0.46 \%$ & $1.55 \%$ & $0.33 \%$ & 4 \\
\hline Undervalued & $0.01 \%$ & $-6.08 \%$ & $-0.04 \%$ & $1.20 \%$ & $1.58 \% * * *$ & 9 \\
\hline Non-repeat & $1.27 \% * * *$ & $1.71 \%$ & $0.38 \% * * *$ & $0.62 \% * * *$ & $0.37 \% * * *$ & 117 \\
\hline Repeat & $1.17 \%$ *** & $-0.46 \%$ & $0.41 \% * * *$ & $0.53 \% * * *$ & $0.59 \% * * *$ & 302 \\
\hline \multicolumn{7}{|l|}{ AUTHORIZATION VALUE } \\
\hline Below median & $1.01 \% * * *$ & $-0.19 \%$ & $0.54 \% * * *$ & $0.95 \% * * *$ & $0.75 \% * * *$ & 209 \\
\hline Above median & $1.40 \% * * *$ & $0.58 \%$ & $0.26 \% * * *++$ & $0.16 \%{ }^{++t}$ & $0.30 \% * * * \dagger$ & 209 \\
\hline \multicolumn{7}{|l|}{ SIZE } \\
\hline Below median & $1.28 \% * * *$ & $0.33 \%$ & $0.45 \% * * *$ & $0.85 \% * * *$ & $0.80 \% * * *$ & 209 \\
\hline Above median & $1.11 \% * * *$ & $-0.07 \%$ & $0.36 \% * * *$ & $0.26 \%$ ***t+ & $0.24 \%$ ***十+ & 209 \\
\hline \multicolumn{7}{|l|}{ BOOK-TO-MARKET } \\
\hline Below median & $1.09 \% * * *$ & $-0.69 \%$ & $0.43 \% * * *$ & $0.68 \% * * *$ & $0.54 \% * * *$ & 209 \\
\hline Above median & $1.30 \% * * *$ & $0.95 \%$ & $0.37 \% * * *$ & $0.47 \% * * *$ & $0.52 \% * *$ & 209 \\
\hline \multicolumn{7}{|l|}{ BASE_SPREAD } \\
\hline Below median & $1.50 \% * * *$ & $0.27 \%$ & $-0.26 \% * * *$ & $0.30 \%$ ** & $0.53 \%$ ** & 209 \\
\hline Above median & $0.90 \% * * *$ & $0.02 \%$ & $1.07 \% * * *,+++$ & $0.82 \% * * *,+\dagger$ & $0.52 \% * * *$ & 209 \\
\hline \multicolumn{7}{|l|}{ PRE_SPREAD } \\
\hline Below median & $0.89 \% * * *$ & $0.98 \%$ & $0.17 \% * * *$ & $-0.55 \%$ ** & $0.09 \%$ & 209 \\
\hline Above median & $1.50 \% * * *$ & $-0.66 \%$ & $0.63 \% * * *,+++$ & $1.67 \% * * *+t++$ & $0.96 \% * * *,+t+$ & 209 \\
\hline \multicolumn{7}{|l|}{ POST_SPREAD } \\
\hline Below median & $1.13 \% * * *$ & $1.41 \%$ & $0.26 \% * * *$ & $0.30 \%$ & $-0.36 \% * * *$ & 209 \\
\hline Above median & $1.22 \% * * *$ & $-1.06 \%$ & $0.53 \% * * *,+$ & $0.81 \% * * *,+\dagger$ & $1.41 \% * * *,+t+$ & 209 \\
\hline
\end{tabular}

Note: XRET is short-term abnormal stock returns estimated from -1 to +1 days around the event. POSTRET is long-run abnormal returns were measured from +6 to +90 days after stock repurchase announcement dates. BASE_SPREAD, PRE-SPREAD and POST_SPREAD respectively are option volatility spreads computed from -50 to -11 , from -10 to -2 and from +1 to +5 days relative to the event date. ${ }^{*}, * *, * * *$ denote significant difference from zero at the $10 \%, 5 \%$ and $1 \%$ levels, respectively; ${ }^{\dagger},{ }^{++},{ }^{++t}$ denote significant difference between below and above median values at the $10 \%, 5 \%$, and $1 \%$ levels, respectively.

\section{Results}

Table 2 reports the results for Equation (3) regressing short-term BHARs on volatility spreads and several control variables. The results showed that the coefficient on PRE_SPREAD was positive but not statistically significant. When we classified PRE-SPREAD based on share repurchase motivations, we

3 These results are similar to Mishra et al. (2011) and De Ridder and Rasbrant (2014).

4 We also split our sample based on below/above median of firm size. We found that, for below median firm size, the association between stock return volatility and implied volatility was statistically insignificant. However, for above median firm size, the relation was positive and statistically significant at the $1 \%$ level. For the sake of brevity, we did not report the result, but they are available upon request. 
found that volatility spreads in the pre-event window were positively associated with announcements motivated by enhancing shareholder value and the stock options plan but this association was only weakly significant. These empirical results suggest that there is no significant evidence that option investors' trade on the direction of stock prices prior to open-market repurchase announcements. Thus, we rejected our first hypothesis and concluded that options investors do not possess private information on the direction of stock price prior to the event.

Table 2. Relationship between short-term Buy and Hold Abnormal Returns (BHARs) and option volatility spreads in the pre-event window.

\begin{tabular}{lcc}
\hline & $\mathbf{1}$ & $\mathbf{2}$ \\
\hline BASE_SPREAD & $-0.73^{* * *}$ & $-0.69 * * *$ \\
PRE_SPREAD & $(-3.23)$ & $(-2.92)$ \\
& 0.15 & \\
Motivations for repurchases & $(1.45)$ & \\
Acquisition purposes & & \\
& & -19.03 \\
Employee benefit plans & $(-0.60)$ \\
& & 0.00 \\
Enhance shareholder value & & $(-0.26)$ \\
& & $0.60 *$ \\
General corporate purpose & $(1.70)$ \\
Other dilution effect & 0.08 \\
& & $(0.38)$ \\
Stock options plan & 0.09 \\
Undervalued & $(0.74)$ \\
& & $1.41 *$ \\
& & $(1.76)$ \\
& & $(-0.15$ \\
\end{tabular}

Note: The dependent variable is short term abnormal returns (XRET). BASE_SPREAD and PRE_SPREAD respectively are option volatility spreads computed from -50 to -11 and from -10 to -2 days relative to the event date. A dummy variable was used for each motivation for repurchase. Control variables (not reported) are a dummy variable if a sample firm launched more than one repurchase program during the sample period, the natural logarithm of the market capitalization of sample firms, the book to market ratio of sample firms and the natural logarithm of the dollar authorization value. The regression model also controls for industry and year effects. In this table we run the regression of Equation (3). **** Denote significant difference from zero at the $10 \%$ and $1 \%$ levels, respectively.

Table 3 reports the results for Equation (4) with long-run BHARs and volatility spreads. The coefficient on POST_SPREAD (in days +1 to +5 ) was positive but not significant. When we split the sample based on repurchase motivations, the results were similar. All the coefficients on POST_SPREAD were insignificant with the exception of the undervaluation motive. The significant (at the five\% level) negative coefficient on POST_UNDV could be due to investor overreaction. When a firm explicitly states undervaluation as its motivation to launch an open market share repurchase program, option investors may expect that the firm's stock price will increase and, subsequently, trade on the firm's call options. However, the mean of post-event abnormal returns reported in Table 1 was negative, which suggests that option investors do not have superior skills in interpreting information from publicly-disclosed announcements. Overall, the results reported in Table 3 were inconsistent with our first hypothesis- that is, options investors do not have superior skills to produce information on the direction of stock prices during the post event period. 
Table 3. Relationship between long-term BHARs and option volatility spreads in the post-event window.

\begin{tabular}{lcc}
\hline & $\mathbf{1}$ & $\mathbf{2}$ \\
\hline BASE_SPREAD & -0.85 & -1.21 \\
PRE_SPREAD & $(-1.13)$ & $(-1.55)$ \\
XRET & 0.13 & 0.18 \\
& $(0.39)$ & $(0.52)$ \\
POST_SPREAD & -0.25 & -0.19 \\
& $(-1.42)$ & $(-1.03)$ \\
Motivations for repurchases & 0.01 & \\
Acquisition purposes & $(0.03)$ & \\
& & \\
Employee benefit plans & & 5.40 \\
& & $(0.44)$ \\
Enhance shareholder value & & -5.49 \\
& & $(-0.55)$ \\
General corporate purpose & & 0.20 \\
& & $(0.19)$ \\
Other dilution effect & & $(0.12$ \\
Stock options plan & & -1.71 \\
Undervalued & & $(-0.44)$ \\
& & -19.37 \\
& & $(-1.41)$ \\
& & $-5.96^{* * *}$ \\
& & $(-2.36)$ \\
\hline
\end{tabular}

Note: The dependent variable is long term abnormal returns (POSTRET). XRET is short term abnormal returns. BASE_SPREAD, PRE-SPREAD and POST_SPREAD respectively are option volatility spreads computed from -50 to -11 , from -10 to -2 and from +1 to +5 days relative to the event date. A dummy variable was used for each motivation for repurchase. Control variables (not reported) are a dummy variable if a sample firm launched more than one repurchase program during the sample period, the natural logarithm of the market capitalization of sample firms, the book to market ratio of sample firms and the natural logarithm of the dollar authorization value. The regression model also controls for industry and year effects. where POSTRET $(+6,+90)_{i}$ is the long-run BHAR for the $i$ th stock; BASE_SPREAD, PRE_SPREAD, and POST_SPREAD are the option implied spreads for days -50 to -11 , -10 to -2 , and +1 to +5 , respectively; $X R E T_{i}$ is the -1 to +1 BHAR for the $i$ th stock; control variables are defined in the Appendix; year and industry are fixed effects; and a number of share repurchase motives are shown below. In regression model 2 results, POST_SPREAD was split based on the motivations for share repurchases; ** Denote significant difference from zero at the $5 \%$ levels, respectively.

The insignificant relationships between stock returns and volatility spreads both before and after share repurchases suggest that options traders do not trade on expected changes in stock prices. Instead, as observed by Figlewski and Frommherz (2017), Gharghori et al. (2017), and Chen et al. (2014), transactions in options markets may be related to the expected volatility of changes in underlying stock values. Thus, we next turned to empirical tests of post-event relationships between option volatility spreads and stock return volatility in line with our second hypothesis.

Table 4 gives summary statistics for the stock return volatility variables (i.e., STDEVSHORT and STDEVLONG, corresponding to days -1 to +1 as well as +6 to +90 , respectively). All mean values of the volatility measures were significantly different from zero. Short-run (long-run) volatility was markedly higher than the mean of the total sample for repurchases intended for acquisition or undervalued purposes (stock option plan and undervalued purposes). More relevant to our research hypothesis, both short- and long-term stock return volatility were significantly higher (at the $10 \%$ level) in stocks with above median values of implied volatility spread (in both the pre- and post-event windows corresponding to days -10 to -2 and +1 to +5 , respectively). Hence, this univariate test suggested that implied volatility spread is predictive of subsequent stock return volatility. 
Table 4. Summary statistics for stock return volatility.

\begin{tabular}{lcc}
\hline \multicolumn{1}{c}{ Dependent Variable } & STDEVSHORT & STDEVLONG \\
\hline Total sample & $0.021^{* * *}$ & $0.017^{* * *}$ \\
Motivations for repurchases & $0.033^{* * *}$ & $0.017^{* * *}$ \\
$\quad$ Acquisition purposes & $0.015^{* * *}$ & $0.015^{* * *}$ \\
Employee benefit plan & $0.023^{* * *}$ & $0.018^{* * *}$ \\
Enhance shareholder value & $0.021^{* * *}$ & $0.017^{* * *}$ \\
General purposes & $0.018^{* * *}$ & $0.019^{* * *}$ \\
Offset dilution & $0.019^{* * *}$ & $0.032^{* * *}$ \\
Stock option plan & $0.034^{* * *}$ & $0.030^{* * *}$ \\
Undervalued & & \\
Sort based on PRE_SPREAD & $0.020^{* * *}$ & \\
Below median & $0.023^{* * *+\dagger}$ & \\
Above median & & $0.016^{* * *}$ \\
Sort based on POST_SPREAD & & $0.019^{* * *, \dagger}$ \\
Below median & & \\
Above median & &
\end{tabular}

Note: This tables gives mean values of stock return volatility and statistical tests for differences from zero. The variables STDEVSHORT and STDEVLONG are the average standard deviation of returns for sample stocks in the short-term event window ( -1 to +1 days) and long-term event window ( +6 to +90 days), respectively. Subsample results are shown for different motivations for share repurchases. Also, mean values are shown for subsamples sorted by above and below median value of their PRE_SPEAD and POST_SPREAD option implied volatilities in the pre- and post-event windows, covering days -10 to -2 and days +1 to +5 , respectively; ${ }^{* * *}$ Denotes significant difference from zero at $1 \% .{ }^{\dagger}$ Denotes significant difference between below and above median values at $10 \%$.

Table 5 displays the regression results for Equations (5) and (6) relating stock return volatility to prior option implied spreads. The PRE_SPREAD and POST_SPREAD results in Panels A and B, respectively, provide short- and long-term evidence. The short-run evidence in Panel A (column 1) for the total sample indicates that volatility spreads were significantly related to subsequent stock return volatility. This result is corroborated by the long-term evidence in Panel B (column 1). Also, they confirm earlier work by Chen et al. (2014), who found that implied volatility of call and put options predicts future stock return volatility in Taiwan. The results reported in Table 5 confirmed our second hypothesis-namely, options investors possesses private information on the volatility of stock returns prior to the event and have superior skills to process event information on the volatility of stock returns during the post event period.

When we split PRE_SPREAD and POST_SPREAD into subsamples based on the reasons for repurchase programs, the results suggested that informed options trading occurs only in selected open-market share repurchase programs. A short-term relationship was evident for acquisition, general purpose, and undervalued motives, which can be interpreted to mean that some informed option investors have private information prior to unscheduled share repurchases. Also, a long-term relationship was significant for general purpose, stock option plan, and undervalued purposes, which implies that informed option investors have superior ability in processing publicly disclosed information after repurchase events.

Table 6 displays the results of the regressions between the daily changes of the components of volatility spread, which are the daily changes of implied volatilities of call and put options matched on strike price and maturity, and stock return volatilities several days prior to and after the announcement date. Panel A of Table 6 shows that, on average, changes in implied volatilities of call and put options 4 days prior to the announcement date were significantly related to stock return volatility. Also, in Panel $B$, the association between stock return volatilities and the daily changes in implied volatilities of call and put options in the post announcement period was significant on day +1 and day +5 . These results are consistent with the notion that option traders significantly trade on the impending announcement 4 days before and 1 to 5 days after an open-market share repurchase announcement. 
Table 5. Relationship between option implied spreads and volatility spreads in the pre- and post-event windows.

\begin{tabular}{cccccccc}
\hline \multicolumn{7}{c}{ Panel A. Results for PRE_SPREAD } \\
\hline Total & \multicolumn{7}{c}{ Subsample sorted by motivation for share repurchases } \\
Sample & PRE_ACQ & PRE_EMPL & PRE_ENH & PRE_GEN & PRE_DIL & PRE_STO & PRE_UNDV \\
\hline $0.08^{* * *}$ & $7.19^{*}$ & 0.00 & 0.16 & $0.10^{*}$ & 0.05 & 0.07 & $0.48^{* * *}$ \\
$(2.59)$ & $(1.72)$ & $(-0.47)$ & $(1.30)$ & $(1.93)$ & $(1.22)$ & $(0.25)$ & $(2.63)$ \\
\hline \multicolumn{7}{c}{ Panel B. Results for POST_SPREAD } \\
\hline Total & \multicolumn{7}{c}{ Subsample sorted by motivation for share repurchases } \\
Sample & POST_ACQ & POST_EMPL & POST_ENH & POST_GEN & POST_DIL & POST_STO & POST_UNDV \\
\hline $0.04^{* *}$ & -0.23 & -0.07 & 0.08 & $0.03^{*}$ & 0.04 & $1.84^{* * *}$ & $0.63^{* * *}$ \\
$(2.41)$ & $(-0.37)$ & $(-0.14)$ & $(1.58)$ & $(1.75)$ & $(0.18)$ & $(3.19)$ & $(5.21)$ \\
\hline
\end{tabular}

Note: The dependent variable of the regression model in Panel A (Panel B) is the standard deviation of the daily market-adjusted returns in the short-term window period from -1 to +1 days $(+6$ to +90 days after the announcement date). PRE_SPREAD (POST_SPREAD) is the option implied spreads for days -10 to $-2(+1$ to +5$)$. Option volatility spreads were computed for subsamples sorted by their motivation for share repurchases: acquisition purposes ( $P R E \_A C Q$ and POST_ACQ), employee benefit plans (PRE_EMPL and POST_EMPL), enhance shareholder value (PRE_ENH and POST_ENH), general corporate purpose (PRE_GEN and POST_GEN), other dilution effect (PRE_DIL and POST_DIL), stock options plan (PRE_STO and POST_STO), and undervalued stock (PRE_UNDV and POST_UNDV); ${ }^{*}{ }^{* *},{ }^{* * *}$ Denote significant difference from zero at the $10 \%, 5 \%$, and $1 \%$ levels, respectively.

Table 6. Relationship between stock return volatilities and the daily changes in the components of implied volatility spread.

\begin{tabular}{cccccccccc}
\hline \multicolumn{4}{c}{ Panel A. Pre-Announcement Date } & \multicolumn{5}{c}{ Panel B. Post-Announcement Date } \\
\hline DAY & CALL & $\boldsymbol{t}$-Stat & PUT & $\boldsymbol{t}$-Stat & DAY & CALL & $\boldsymbol{t}$-Stat & PUT & $\boldsymbol{t}$-Stat \\
\hline-5 & $-0.031^{*}$ & -1.83 & 0.000 & -0.01 & +1 & $0.030 * *$ & 2.84 & 0.007 & 0.61 \\
-4 & $0.044^{* * *}$ & 2.73 & $0.034^{*}$ & 1.85 & +2 & 0.008 & 0.88 & -0.006 & -0.68 \\
-3 & -0.004 & -0.23 & 0.014 & 1.14 & +3 & 0.007 & 0.85 & 0.008 & 1.05 \\
-2 & 0.031 & 1.61 & -0.005 & -0.38 & +4 & 0.001 & 0.08 & 0.003 & 0.31 \\
-1 & 0.001 & 0.09 & 0.008 & 0.57 & +5 & $-0.029^{* * *}$ & -3.01 & $-0.023^{* *}$ & -2.52 \\
\hline
\end{tabular}

Note: The dependent variable of the regression model in Panel A (Panel B) is the standard deviation of the daily market-adjusted returns in the short-term window period from -1 to +1 days $(+6$ to +90 days after the announcement date). ${ }^{*}, * *$ Denote significant difference from zero at the $10 \%$ and $1 \%$ levels, respectively.

\section{Robustness Tests}

Following Gharghori et al. (2017), we replaced volatility spread with daily changes in implied volatility of call and put options around the event instead of volatility spread as our measure of informed options trading. However, these daily changes in implied volatilities of call and put options were not matched with respect to their strike price and maturities. We found the results were qualitatively similar to those reported in Table 5-that is, option traders significantly trade 4 to 3 days prior to the announcement date and on day 1 to 3 days after the announcement date. Overall, the results are consistent with the results of our previous tests that informed options trading related to stock return volatility occurs around open-market share repurchase announcements.

\section{Conclusions}

Prior studies suggest that informed investors prefer trading in option markets rather than in stock markets. Our study tested this conjecture by examining the relationships between implied volatility spread measured around open-market share repurchase announcements and abnormal stock return as well as stock return volatility around this event. Because share repurchases are unscheduled, only investors who have private information related this event can benefit from their trading.

Based on our empirical evidence, we concluded that, on average, option investors do not have superior information on the direction of stock prices related to open-market share repurchase 
announcements, but do trade on the volatility of the underlying stock returns around this event. Hence, option investors may not always have full private information prior to an unanticipated event.

Author Contributions: All authors equally contributed to the paper.

Funding: This research received no external funding.

Conflicts of Interest: The authors declare no conflict of interest.

\section{References}

Badshah, Ihsan, Hardjo Koerniadi, and James Kolari. 2019. The Sarbanes-Oxley Act and informed trading in the options market: Evidence from share repurchase announcements. International Review of Finance. [CrossRef]

Black, Fischer. 1975. Fact and fantasy in the use of options. Financial Analyst Journal 31: 36-41, 61-72. [CrossRef]

Chan, Kalock, Peter Chung, and Wai-Ming Fong. 2002. The informational role of stock and option volume. Review of Financial Studies 15: 1049-75. [CrossRef]

Chan, Konan, Li Ge, and Tse-Chun Lin. 2015. Informational content of option trading on acquirer announcement returns. Journal of Financial and Quantitative Analysis 50: 1057-82. [CrossRef]

Chen, Chin-Ho, Huimin Chung, and Shu-Fang Yuan. 2014. Deviations from put-call parity and volatility prediction: Evidence from the Taiwan Index Option Market. Journal of Futures Market 34: 1122-45. [CrossRef]

Cremers, Martijn, and David Weinbaum. 2010. Deviations from put-call parity and stock return predictability. Journal of Financial and Quantitative Analysis 45: 335-67. [CrossRef]

De Ridder, Adri, and Jonas Rasbrant. 2014. Share repurchases: Does frequency matter? Studies in Economics and Finance 31: 88-105. [CrossRef]

Easley, David, Maureen O'Hara, and Pulle Subrahmanya Srinivas. 1998. Options volume and stock prices: Evidence on where informed traders trade. Journal of Finance 53: 431-65. [CrossRef]

Figlewski, Stephen, and Anja Frommherz. 2017. Volatility leadership among index options. Journal of Derivatives 25: 43-60. [CrossRef]

Gharghori, Philip, Edwin D. Maberly, and Annette Nguyen. 2017. Informed trading around stock split announcements: Evidence from the options market. Journal of Financial and Quantitative Analysis 52: 705-35. [CrossRef]

Hao, Qing. 2016. Is there information leakage prior to share repurchase announcements? Evidence from daily options trading. Journal of Financial Markets 27: 79-101. [CrossRef]

Holowczak, Richard, Yusif E. Simaan, and Liurin Wu. 2006. Price discovery in the U.S. stock and stock options markets: A portfolio approach. Review of Derivatives Research 9: 37-65. [CrossRef]

Hsu, Yuan-Teng, and Chia-Wei Huang. 2016. Idiosyncratic risk and share repurchases. Finance Research Letters 18: 76-82. [CrossRef]

Jin, Wen, Joshua Livnat, and Yuan Zhang. 2012. Options prices leading equity prices: Do options traders have an information advantage? Journal of Accounting Research 50: 401-31. [CrossRef]

Kim, Jaemin. 2007. Buyback trading of open-market share repurchase firms and the return volatility decline. International Journal of Managerial Finance 3: 316-37. [CrossRef]

Kim, Oliver, and Robert E. Verrecchia. 1991. Market reaction to anticipated announcements. Journal of Financial Economics 30: 273-309. [CrossRef]

Kim, Oliver, and Robert E. Verrecchia. 1994. Market liquidity and volume around earnings announcements. Journal of Accounting and Economics 17: 41-67. [CrossRef]

Mishra, Dev, Marie D. Racine, and Luke Schmidt. 2011. Credibility of corporate announcements and market reactions: Evidence from Canadian share repurchase programs. Canadian Journal of Administrative Sciences 28: 83-100. [CrossRef]

Pan, Jun, and Allen M. Poteshman. 2006. The information in option volume for future stock prices. Review of Financial Studies 19: 871-908. [CrossRef]

Patell, James M., and Mark A. Wolfson. 1981. The ex ante and ex post price effects of quarterly earnings announcements reflected in option and stock prices. Journal of Accounting Research 19: 434-58. [CrossRef]

Peyer, Urs C., and Theo Vermaelen. 2005. The many facets of privately negotiated stock repurchases. Journal of Financial Economics 75: 361-95. [CrossRef] 
Roll, Richard, Eduardu Schwartz, and Avanidhar Subrahmanyam. 2010. O/S: The relative trading activity in options and stocks. Journal of Financial Economics 96: 1-17. [CrossRef]

Vafeas, Nikos. 1997. Determinants of the choice between alternative share repurchase methods. Journal of Accounting Auditing Finance 12: 101-24. [CrossRef]

Xing, Yuan, Xiaonyan Zhang, and Rui Zhao. 2010. What does the individual options volatility smirk tell us about future equity returns? Journal of Financial and Quantitative Analysis 45: 641-62. [CrossRef] 